\title{
TELAAH PEMIKIRAN MUHAMMAD FAZLUR RAHMAN TENTANG ISLAM DAN PERADABAN BARAT MODERN
}

\author{
Muhamad Hakim \\ Dosen Sekolah Tinggi Ilmu Syariah (STIS) Kebumen Jawa Tengah \\ E-mail:m.hakim@gmail.com.
}

\begin{abstract}
Abstrak
Perkembangan pemikiran Islam Modern adalah merupakan bentuk upaya intelektual dalam mempertahankan ajaran Islam dengan mencermati bahkan menolak doktrindoktrin lain yang berlawanan serta mencoba mengulas kedudukan kehidupan Islam secara umum. Sebagai Modernisasi dan Reformasi, Muhammad Fazlur Rahman berusaha memadukan penilaian Islam murni (turats) yang bersumber dari AlQur'an dan Sunnah, dan studi-studi modern untuk mengangkat spiritual dan moral masyarakat-masyarakat Islam di Timur jauh dan di Barat. Ide Struktur Iman yang memiliki warna etika dan ide tauhid dalam Islam dari Fazlur Rahman merupakan konsep dan sebagai pandangan hidup muslim agar mampu dan eksis menjalani kehidupan modern dan tetap Islam. Sejalan dengan dinamika kehidupan masyarakat modern berjalan terus dan selalu berubah, maka konsep yang ditawarkan Fazlur Rahman tersebut masih cukup relefan untuk saat ini, akan tetapi untuk eksisnya konsep tersebut perlu pemahaman yang komprehensip, kontekstual dan iftikad yang dilakukan terus menerus. Pendekatan dalam tulisan ini menggunakan studi tokoh dengan pendektan sejarah intelektual tentang perkembangan Islam modern dalam bingkai peradaban Barat secara seimbang antara Islamic Civilization and Weast.
\end{abstract}

Kata Kunci: Islam, Peradaban Barat, Modern, Fazlur Rahman 


\section{A. Pendahuluan}

Pemikiran Islam Modern merupakan kegiatan intelektual Ulama Islam untuk menerangkan ajaran Islam dari sumber aslinya yaitu: kitab suci Al-Qur'an dan sunnah Nabi Muhammad SAW sebagai usaha memahami atau istimbat hukum-hukum agama baik dalam dataran hubungan manusia dengan Tuhan dalam bentuk ibadah ataupun hubungan antara manusia dalam muamalat. Termasuk dalam kegiatan ini adalah mencarikan jalan keluar peristiwa baru yang belum ada prosedurnya pada masa Nabi Muhammad SAW.

Sebagai suatu bentuk pemikiran, di dalam perkembangannya, pemikiranpemikiran di masa modern, oleh DR. Harun Nasution berpendapat bahwa di periode modern ini muncul ide-ide pembaharuan dalam Islam, periode modern dalam sejarah Islam mulai tahun $1800 \mathrm{M}$ sampai sekarang. Masa ini merupakan zaman kebangkitan umat Islam. Jatuhnya Mesir ke tangan Barat menyadarkan dunia Islam, akan kelemahannya. Kenyataan ini juga menyadarkan mereka bahwa di Barat telah timbul peradaban baru yang lebih tinggi dan merupakan ancaman bagi umat Islam. Raja-raja dan pemuka Islam mulai memikirkan bagaimana cara meningkatkan kualitas dan kekuatan umat Islam kembali. ${ }^{1}$

Dari sekian banyak pemikir dan modernis Islam India - Pakistan diantaranya adalah Muhammad Fazlur Rahman Al Ansari, Ia memiliki konsep dalam Islam masa modern ini berbeda dengan rumusan-rumusan sebelumnya khususnya tentang ide tauhid dalam Islam. Ide tauhid yang dikonsepkan oleh pemikir ini memiliki banyak kesamaan dengan Ali Syariati, konsepnya sudah tidak lagi menyebutkan problem masa klasik yang menekankan pemahaman, tetapi sudah menukik ke bumi yang menyentuh bidang kehidupan konkrit. Bidang kehidupan yang menjadi lahan kegiatan tauhid juga tidak terbatas, melainkan menjangkau ke semua segi kehidupan.

Lebih lanjut siapa dan bagaimana pemikirannya serta pelajaran apa yang dapat diambil sebagai aktualisasi kebangkitan peradaban Islam Modern abad ke 21, disajikan dengan paparan sederhana sebagai berikut.

Harun Nasution, Islam di Tinjau dari Berbagai Aspeknya, Bulan Bintang, Jakarta, 1974, hlm. 56 


\section{B. Riwayat Hidup Fazlur Rahman}

Nama lengkap Fazlur Rahman ialah Maulana DR. Muhammad Fazlur Rahmam Al Ansari. Ia dilahirkan pada tanggal 21 September 1919 di distrik Hazara - Punjab - Pakistan. Ia dibesarkan dalam suatu keluarga dengan tradisi keagamaan madzhab Hanafi yang cukup kuat. Oleh karena itu, ia telah biasa menjalankan ritual-ritual agama secara teratur sejak masa kecil.

Fazlur Rahman kecil menerima pengajaran dan pendidikan tradisional mengenai kajian-kajian keislaman dari ayahnya sendiri, Maulana Shahab Aldin dan dari Madrasah Deoband. Dalam usia sepuluh tahun ia sudah hafal Al Qur'an 30 juz diluar kepala. Ketika berusia empat belas tahun ia sudah mulai belajar filsafat, bahasa arab, tiologi hadist, tafsir. Intelektualnya semakin teguh dengan penguasaannya dalam berbagai bahasa; Persia, Urdu, Inggris, Perancis, Jerman. Di samping itu juga mempunyai pengetahuan tentang bahasa-bahasa Eropa Kuno seperti Latin, Yunani. ${ }^{2}$

Pada tahun 1940an, ia mendapat gelar Bachelor Art, kemudian gelar Master Doktor (Ph.D) ia juga meneruskan belajarnya ke dunia barat, Universitas Oxford pada tahun 1949. Setelah meraih gelar Doktor, Fazlur Rahman memutuskan untuk tinggal selama beberapa tahun di Barat dengan mengajar di Universitas Durham Inggris. Selanjutnya ia pindah dan mengajar ke Institut of Islamic Studies, Universitas McGill dan menjabat sebagai Assiciate Professor of Philosophy sampai tahun 1960. Pada tahun itu ia kembali ke Paskitan atas panggilan Presiden Pakistan, Ayub Khan, untuk berpartisipasi dalam membangun negara Pakistan.

Ia aktif dalam dunia pendidikan dan mengajar filsafat agama, filsafat moral, perbandingan agama, dan ilmu-ilmu agama Islam kepada para ulama di Akademi Agama Islam di Quetta. Setelah itu mengepalasi Program Pasca Sarjana Universitas Karaci. Kemudian ia mendirikan World Federation of Islamic Missions.

Di atas semua, ia adalah cendekiawan multi demensi, orator, misionaris, dosen, penulis, pemuka spiritual dan pengabdi kemanusiaan dengan segudang pengalaman di seluruh pelosok dunia.

Akhirnya pada tanggal 26 Juli 1988, ia wafat di Amerika Serikat dalam usia 69 tahun setelah beberapa lama sebelumnya ia dirawat di Rumah Sakit Chicago.

2 Abd. A'la, Neomodernisme ke Islam Liberal 2 (Jakarta: Paramadina, 2003), hal 33 


\section{Pemikiran Fazlur Rahman}

\section{Struktur Imam}

Menurut Muhammad Fazlur Rahman Al Ansari, struktur keyakinan iman di dalam Islam adalah sangat murni, konsisten dan tulen bersifat etiko religius yang mencakup kebaikan dunia sampai akhirat. Struktur ini dibangun di atas dasat unsur-unsur keimanan, berdasar pada tujuh kenyataan menurut Al Qur'an.

Tujuh dasar iman dalam Islam tersebut adalah:

1. Allah (Tuhan)

2. Malaikat

3. Rasul-rasul (para Nabi)

4. Kitab-kitab Allah

5. Al Qodar (takdir)

6. Hari Kebangkitan Kembali

7. Kehidupan setelah Qiyamat

- Iman kepada Allah dalam pendapat Muhammad Fazlur Rahman berarti bahwa Allah merupakan sumber tuntunan maupun kekuatan, dan kepribadian-Nya membentuk prinsip evolusi monotik, dihubungkan usaha manusia dalam menunaikan nasibnya.

- Iman kepada rasul-rasul-Nya harus dikaitkan dengan ajaran Al Qur'an bahwa Allah itu satu dan umat manusia itu juga merupakan kesatuan-satuan. Tuntunan dari Tuhan telah turun kepada semua masyarakat dan pada dasarnya semua falsafah hidup dan cara berserah diri kepada Tuhan yang satu adalah sama yaitu Islam. Jika terdapat persamaan-persamaan dalam ajaran berbagai agama, maka hal ini menunjukkan sisa-sisa kebenaran asli yang diwahyukan Tuhan. ${ }^{3}$

Mengenai Al Qur'an, dia berpendapat bahwa kitab suci ini merupakan wahyu tuntunan Tuhan yang terakhir, penutup dan pelengkap. Tiga fungsi utama Al Qur'an adalah:

Fazlur Rahman Al-Ansari, The Qur'anic Foundation and Structures of Muslim Society, (Islamic Publication Ltd, Lahore, 1985), hlm. 25 
1. Menyatakan kembali tuntunan Illahi yang telah turun sebelumnya tetapi kemudian mengalami perubahan.

2. Mengoreksi semua pernyataan yang salah di antara agama.

3. Menyiarkan tuntunan Illahi dalam dimensi yang ditujukan khusus untuk zaman kematangan sejarah peradaban manusia.

- Menurut Al Ansari konsep takdir mengandung pengertian bahwa: Kosmos secara keseluruhan seperti halnya alam manusia yang kecil merupakan suatu kedaulatan hukum dan bukan kedaulatan magis. Oleh karena itu pendekatan religius jangan bersifat magis tetapi harus melalui usaha menegakkan hukum pentakaran yang telah ditetapkan Allah. Sebagai akibatnya kebaikan etiko religius haruslah disesuaikan dengan takaran tersebut.

Beriman dengan hari kebangkitan memiliki beberapa makna yang oleh Al Ansari dirumuskan sebagai berikut:

a. Melebarkan orientasi manusia keluar dari eksistensi duniawi dan dengan demikian menghancurkan akar duniawi yang merupakan biang penyakit moral.

b. Memantapkan kemutlakan nilai kemanusiaan dan nilai moral.

c. Memunculkan nilai antusias moral dan memberikan dasar pemikiran rasional untuk berkorban demi kebaikan.

Hari akhir adalah kelanjutan dari kebangkitan yang hubungannya erat dengan konsep dasar Al Qur'an.

a. Tuhan adalah penguasa Morrar Cosmos

b. Cosmos adalah masyarakat moral

c. Manusia diturunkan sebagai makhluk moral dengan dasar spiritual.

d. Manusia harus menyerahkan kepercayaannya kepada penguasa moral yang menguasai segala-galanya. Oleh karena itu manusia juga harus menghadapi perhitungan akhir. ${ }^{4}$

${ }^{4} \quad$ Ibid, hlm. 96 


\section{Ide Tauhid dalam Islam}

Menurut Fazlur Rahman, Al Qur'an telah meletakkan titik berat terbesar pada konsep kesatuan (tauhid). Konsep ini bukanlah suatu konsep di tengahtengah berbagai konsep, akan tetapi merupakan suatu prinsip lengkap yang menembus semua dimensi yang mengatur seluruh khasanah fundamental, keumanan, dan aksi manusia. Unsur-unsur dari pengertian tauhid yang utuh ini adalah sebagai berikut:

1. Kesatuan Tuhan

Pandangan Al Qur'an berdasarkan prinsip kesatuan Tuhan. Tuhan adalah Esa, tidak berbagi dan tanpa saingan. Dia adalah satu-satunya realita dan beriman kepadanya menurut loyalitas dan penyerahan yang terpecah atau terbagi. Hal ini memerdekakan umat dari segala bentuk ikatan.

2. Kesatuan Alam Semesta

Alam semesta merupakan satu kesatuan baik dalam eksistensi maupun tujuannya. Dengan demikian alam semesta adalah kosmos dan bukan kekacauan. Alam semesta merupakan suatu masyarakat moral dan bukan merupakan pengumpulan partikel banyak tingkah yang a-moral.

3. Kesatuan Hubungan Tuhan dengan Kosmos

Menurut Al Qur'an Tuhan itu mutlak sedangkan alam adalah fana. Yang fana berasal dari yang mutlak.

Dengan demikian yang fana tidak memiliki eksistensi merdeka, sementara yang mutlak tidak terasing dan tidak pula termasuk di dalam yang fana atau relatif.

4. Kesatuan Kehidupan

Karena Al Qur'an menyatakan alam semesta sebagai satu keseluruhan organik yang muncul ke dalam eksistensi melalui aksi penyatuan dari kehendak berada dalam suatu prinsip evolusi penyatuan yang tunggal. Kehidupan manusia, sebelum lahir ke dunia kehidupan duniawinya, kehidupan setelah mati, semuanya membentuk satu kesatuan. Dalam kenyataannya kehidupan ini terikat pada suatu proses evolusi yang berkesinambungan. 
5. Kesatuan Natural dan Supra Natural

Dasar eksistensi semua fenomena dan benda di alam semesta adalah satu, apa yang disebut sebagai natural dan supra natural hanyalah dua tingkat kegiatan yang menembus kosmos yang tidak menimbulkan kontradiksi.

6. Kesatuan Ilmu

Karena alam semesta merupakan kesatuan maka ilmu harus dicari berdasarkan suatu kesatuan dalam arti bahwa ilmu harus dibentuk dan harus membentuk satu "keseluruhan".

Cabang ilmu pengetahuan yang berbeda harus dianggap sebagai hubungan dari kesaling bergantungan. Tidak ada alasan untuk membagi ilmu menjadi religius dan sekuler.

7. Kesatuan Iman dan Rasio

Pemahaman ilmu dan pemahaman iman bukanlah anti thetik, keduanya merupakan dimensi-dimensi dari kesadaran manusia yang sama. Oleh karena itu iman dan rasio akan menyeret manusia kepada takhayul, dan rasio tanpa iman merintangi manusia mencapai nilai tertinggi.

8. Kesatuan Kebenaran

Di dalam tuntunan-Nya Tuhan telah membeberkan kebenaran pokok, dan menyeluruh manusia untuk mengajinya. Kebenaran tidak memiliki faset-faset yang berbeda-beda, karena hanya memiliki satu sisi. Pengamatan indera dan rasio manusia yang terbataslah yang memberikan pandangan sepotong-potong dan membuahkan kesimpulan sebagian dari keseluruhan kebenaran.

9. Kesatuam Agama

Al Qur’an mengajarkan bahwa Tuhan itu satu, manusia juga satu, oleh karena itu tuntutan Illahi tidak terbatas pada suatu ras tertentu. Tuntutan Illahi memberikan prinsip kesatuan. Adapun campur tangan manusia di dalam wajah Tuhan telah diluruskan Al Qur'an. Kembali ke ajaran asli dengan bantuan rasio dan Al Qur'an akhirnya menjadikan agama-agama tersebut menjadi kesatuan dalam kebenaran Illahi serta meratakan jalan menuju kesatuan umat. 
10. Kesatuan Kasih Sayang dan Hukum

Fungsi kasih sayang dan ketegasan dalam hukum merupakan batang tubuh aturan bertindak manusia. Menurut Al Qur'an berkembangnya manusia murni hanya mungkin bila kasih sayang dan hukum berfungsi dalam kehidupan manusia sebagai kesatuan organis.

11. Kesatuan Umat

Menurut Al Qur'an jenis kemanusiaan merupakan kesatuan umat. Dengan demikian semua praduga ras, warna kulit, kasta dan kelamin di tentang dan dibasmi. Perbedaan satu-satunya adalah prestasi moral yang dicapainya.

12. Kesatuan Pria Wanita

Dilihat fungsi maka pria dan wanita memiliki perbedaan. Akan tetapi menurut Al Qur'an keduanya berasal dari satu tubuh. Oleh karena itu dalam hakekat kemanusiaan yang pokok, mereka disatukan di dalam ikatan kemanusiaan. Mereka satu dan sama, dalam fungsinya mereka saling mengisi.

13. Kesatuan Kepribadian

Menurut Al Qur'an jenis kemanusiaan itu merupakkan kesatuan baik dari jiwa, pendirian, tubuh, dimensi-dimensi eksistensi dan perilakunya yang berbeda-beda. Kesatuan ini merupakan keutuhan dimana seluruh kepribadian manusia : fisik, moral, rasio, estestika, spiritual secara lengkap dan serasi harus dikembangkan untuk memenuhi keinginan serta ketentuan Illahi.

14. Kesatuan Kemerdekaan dan Determinisme

Menurut Al Qur'an bukanlah budak nasib, tetapi bukan pula pembuat tunggal nasibnya sendiri. Kedua kutub ini diselaraskan oleh Al Qur'an. Ketika Tuhan mencipta manusia, diberinya kepribadian dan kemerdekaan meskipun tidak mutlak tetapi memadai untuk ukuran manusia. Tuhan adalah "sekutu" manusia yang tetap, dan baik manusia maupun Tuhan ikut andil dalam menciptakan nasib manusia. Partisipasi timbal balik ini membentuk medium di mana kemerdekaan dan determinisme tegak sebagai kesatuan. 
15. Kesatuan Kehidupan Sosial Pokok

Islam menghapus lembaga kependetaan dan perbedaan kelas sosial seperti kasta dalam Hindhu. Al Qur'an membuka jalan terbentuknya suatu masyarakat yang dibaktikan untuk kebajikan, dan meletakkan sistem di mana satu-satunya kriteria superioritas hanyalah prestasi moral dan spiritual.

16. Kesatuan Politik

Islam telah mampu menghapus kekejian akibat kemutlakan pihak penguasa atau pemusnahan hak para rakyat dan bawahan. Al Qur'an menyelesaikan problema ini dengan menyatukan bawahan dan atasan di bawah perintah prinsip supremasi hukum. Tidak hak bagi perorangan untuk memerintah satu terhadap lainnya karena hanya merupakan wewenang hukum yaitu hukum Allah.

17. Kesatuan Agama dan Negara

Pemisahan antara agama dan negara di dalam kehidupan bernegara akan membawa masyarakat kepada kesengsaraan spiritual dan penipuan berdasar organisasi kebijakan. Al Qur'an mengemukakan konsep kehidupan bernegara dengan upaya terorganisasi untuk memperoleh kebutuhan seutuhnya.

18. Kesatuan Ekonomi

Baik liberalisme ekonomi yang melahirkan kapitalisme ataupun komunisme ternyata membawa ke jurang kehancuran. Al Qur'an menyelesaikan masalah ini dengan konsep kesatuan ekonomi yang menggabungkan antara kemerdekaan dan persamaan melalui pengambilan nilai keadilan sebagai landasan didirikannya masyarakat manusia.

19. Kesatuan Kelas

Ketidaksamaan-ketidaksamaan manusia serta pengkotak-kotak kuantitatif dan kualitatif sudah merupakan hakekat kehidupan sosial manusia. Akan tetapi pemerasan serta ketidak adilan dari perbedaan ini adalah tidak wajar. Oleh karena itu Al Qur'an mengemukakan konsep:

1) Menitik beratkan dasar manusiawi terhadap kehidupan sosial,

2) Menghapuskan gagasan pengkotakan sosial 
3) Menghancurkan Feodalisme dan Kapitalisme

4) Menghapus eksploitasi dan tidak adil

5) Mewujudkan masyarakat sejahtera berdasar ketakwaan, kebenaran dan keadilan.

20. Kesatuan cita dan tujuan

Pada tingkat kejiwaan, moral dan fenomena sosial, Al Qur'an mengambil bentuk integrasi. Oleh karena itu satu-satunya tujuan adalah menunaikan fungsinya sebagai khalifah Tuhan di bumi. Tujuan tunggal ini merupakan tujuan yang lengkap dimana tujuan sekunder harus diarahkan ke arah ini.

\section{Analisa dan Refleksi}

Adalah suatu tuntunan yang sangat pokok bagi suatu agama yang primitif maupun yang beradab, yang diwahyukan maupun yang tidak diwahyukan untuk menjelmakan keyakinan-keyakinan pokoknya dalam suatu keyakinan "Iman". Keyakinan agama yang berbeda pada hakikatnya berbeda pula. Di samping sejarah, keyakinan-keyakinan tersebut juga berbeda dalam pendekatan dasarnya kepada pribadi manusia serta hubungannya dengan apa yang masingmasing agama anggap sebagai realita tertinggi. Di antara berbagai agama yang berorientasi ke spiritual, sebagaimana memaki pendekatan yang pada dasarnya bersifat mitologis, pola pendekatan yang seperti ini akan melumpuhkan jika bersemangat mistik dan menjadi dinamis jika bersemangat etika religius.

Sama seperti Al Maududi, Muhammad Fazlur Rahman Al Ansari mencoba menyodorkan sesuatu kerangka kebenaran orang menerima yang mampu mencerminkan tujuan risalah Nabi Muhammad SAW di abad modern ini, jika konsep Al Maududi bertumpu pada ide "iman sebagai kontrak jual beli" maka Al Ansari mengajukan konsep yang bertumpu pada "struktur iman untuk mewujudkan kebaikan utama” ide dasar yang diajukan Al Ansari ini dimungkinkan oleh komponen dasar struktur iman yang memiliki warna etika religius.

Dengan semangat etika religius ini maka struktur iman mampu mendorong terwujudnya kebaikan utama di dalam kehidupan manusia karena 
unsur-unsur dengan tabiat khusus. Allah adalah ideal kebaikan sempurna yang supra kosmis sebagai pemilik keselarasan mutlak dalam semua deminasi kesempurnaannya. Malaikat adalah ideal kebaikan utama yang bersifat kosmik, sedangkan para Rosul adalah ideal kebaikan utama yang manusiawi. Dengan bantuan para Rosul ini maka manusia mampu memahami kitab-kitab suci yang mewakili tuntunan Ilahi untuk meraih kebaikan utama bagi manusia. Di dalam pencarian ini maka Al Qadar membentuk norma-norma pokok agar tercapai kebaikan utama yang didambakan. ${ }^{5}$

Jaminan pencapaian kebaikan utama oleh manusia dilestarikan oleh keyakinan akan kebangkitan kembali di mana pemenuhan nabis manusia untuk memiliki kebaikan utama ditegaskan oleh keyakinan tentang akhirat.

Pernyataan bahwa Islam adalah agama Tauhid dapat diterima oleh ulama-ulama Islam. Bahkan dibandingkan dengan agama-agama samit yang lain, Islam menyodorkan rumusan pengerian tauhid yang paling murni dan utuh. Di dalam menyebarkan rumusan pengertian tauhid ini maka sejak para Mutakallimin klasik berbagai konsep dan rumusan telah dikemukakan. Rumusan-rumusan pengertian tauhid berbeda, baik dalam sudut pandangan maupun kerangka dasar bahasanya, seperti Mu'tazilah, Ibnu Taimiyah, ataupun Ibnu Abdul Wahab.

Dampak ilmu dan tehnologi modern tidak sepenuhnya positif baik kehidupan manusia di dunia maupun akhirat. Ilmu dan tehnologi khususnya dan buah dari perkembangannya di dunia modern ternyata harus dibayar mahal oleh umat manusia yaitu makin terancamnya makna kemanusiaan. Kecenderungan inilah sebenarnya yang juga merupakan ancamanide tauhid di dalam Islam. Untuk menghadapi gejala ini dan sekaligus menyodorkan jalan keluar bagi umat Islam, maka para Modernis mengemukakan rumusan pengertian Tauhid yang berbeda dari Mu'tazilah dan Ibnu Abdul Wahab.

Berbeda dari rumusan aliran Mu'tazilah di masa klasik, karena rumusan modern ini tidak ditekankan pada dimensi pemahaman melainkan bentuk amaliyah yang sifatnya konkrit dan aktif. Jika dibandingkan dengan rumusan Ibnu Abdul Wahab memang sama-sama menekankan dimensi amaliyah

\footnotetext{
Ali Syanafi, Sosiologi Islam, (Jakarta: Bulan Bintang, 1982), hlm. 54
} 
namun bidang kegiatan di dalam kegiatan rumusan modern ini lebih luas dan mencakup seluruh bidang kehidupan manusia.

Ide tauhid bukan semata-mata gagasan methaphisis yang terlepas dari kehidupan kongkrit melainkan sebagai suatu pandangan hidup. Pandangan hidupnya adalah tauhid. Dalam hal ini tauhid menunjuk pada pengertian keesaan Allah, tetapi lebih dari itu tauhid sebagai pandangan hidup adalah pandangan bahwa seluruh alam semesta sebagai pandangan hidup adalah pandangan bahwa seluruh alam semesta sebagai satu kesatuan, pandangan seluruh eksistensi sebagai suatu bentuk tunggal suatu organisme tunggal, yang hidup dan memiliki kesadaran cipta, rasa dan karsa.

Sebaliknya syirik adalah suatu pandangan hidup yang melihat alam semesta sebagai suatu kumpulan yang kacau, penuh dengan keanekaan, kontradeksi dan hetergenitas. Di dalam terdapat serba ragam katub yang satu sama yang lain tidak ada hubungannya, bahkan saling bertentangan, penuh kecenderungan konflik, dengan seribu keinginan, perhitungan, kebiasaan, tujuan dan kehendak sendiri-sendiri. Tauhid memandang dunia sebagai suatu imperium, sedangkan Sirik memandangnya sebagai suatu sistem feodal.

Ide tauhid dalam Islam menurut pemikiran Muhammad Fazlur Rahman secara ideal memang sudah memberi solusi pandangan hidup di zaman modern, akan tetapi konsep yang ditawarkan tersebut masih bersifat global atau masih bersifat bahan baku, oleh karena itu agar memiliki makna dan membumi pada jiwa umat manusia setiap zaman, perlu adanya upaya konkritisasi dan proses pembumian berdasar kebutuhan lokal dan aktual. Proses reaktualisasi dan transformasi berbagai nilai positif agama Islam dalam konteks kontemporer inilah yang akan membantu bagi tumbuhnya etos baru kerja pembangunan yang orisinal yang dibutuhkan zaman baru.

Bila Islam dan para tokoh agama Islam tidak bergerak memasuki ruang percepatan transformasi sosial, atau jawaban-jawaban agama terhadap sosial tidak memadai atau bahkan tidak lagi dirasakan sebagai jawaban maka agama Islam akan mengalami fosilisasi secara perlahan namun pasti.

Oleh karena itu hubungan pengertian tauhid yang lebih penting adalah implikasi praktisnya di dalam kehidupan manusia. Melalui ide tauhid ini, Islam membersihkan agama dari segala bentuk kekaburan. Pola penting untuk zaman 
kita sekarang ini, bukanlah bentuk esoteris dan problem peribadatan individual dari ajaran agama tapi justru bentuk eksoterisnya dan permasalahan sosial.

Secara filosofis kenyataan ini dapat dilandaskan pada argumentasi yang menyatakan:

1. Setiap esensi atau dimensi esiteris agama tanpa adanya eksistensi atau bentuk eksoteris tidak dapat menimbulkan efek, karena yang asasi dan sumber efek adalah eksistensi dan bukan asensi. Agama akan menjadi sesuatu yang absurd dan sekedar menjadi bayangbayang bila tidak dikebumikan pada tataran sosiologis antripologis.

2. Esensi itu sendiri netral dalam hal intensitas dan kelemahan, prioritas dan posterioritas. Artinya terlepas dari eksistensi, esensi tidak intens, tidak lemah, tidak prior dan tidak posterior. Jika eksistensi tidak dianggap asasi, maka kita harus menganggap esensi yang tidak mempunyai atribut sebagai sumber atribut.

3. Eksistensi merupakan realitas dasar yang diperlukan untuk membentuk esensi sebagai sebuah preposisi. Tanpa eksistensi, esensi tidak berarti apa-apa. ${ }^{6}$

\section{E. Kesimpulan}

Pemikiran Islam Modern adalah merupakan bentuk upaya intelektual dalam mempertahankan ajaran Islam dengan mencermati bahkan menolak doktrin-doktrin lain yang berlawanan serta mencoba mengulas kedudukan kehidupan Islam secara umum. Sebagai Modernisasi dan Reformasi, Muhammad Fazlur Rahman berusaha memadukan penilaian Islam murni yang bersumber dari Al Qur'an dan Sunnah Rosul SAW dan studi-studi modern faraf dan aktif untuk mengangkat spiritual dan moral masyarakatmasyarakat Islam di Timur jauh dan di Barat.

Ide Struktur Iman yang memiliki warna etika dan ide tauhid dalam Islam dari Muhammad Fazlur Rahman merupakan konsep dan sebagai pandangan hidup muslim agar mampu dan eksis menjalani kehidupan modern dan tetap

${ }^{6}$ Ahmad Najib Burhani, Islam Dinamis, (Jakarta: PT. Kompas Media Nusantara), hlm. 206-207 
Islam. Sejalan dengan dinamika kehidupan masyarakat modern berjalan terus dan selalu berubah, maka konsep yang ditawarkan Fazlur Rahman tersebut masih cukup relefan untuk saat ini, akan tetapi untuk eksisnya konsep tersebut perlu pemahaman yang komprehensip, kontekstual dan iftikad yang dilakukan terus menerus.

Demikian makalah ini penulis susun, dengan segala keterbatasan penulis telah berusaha dan berupaya semaksimal mungkin untuk menyajikan makalah ini sebaik mungkin, namun kekurangan leteratur dan keterbatasan waktu yang tersedia sehingga hasilnya belum bisa maksimal sebagaimana yang diharapkan, namun dengan segala kekurangannya ini mudah-mudahan dapat menjadikan pemicu untuk lebih semangat lagi bagi penulis untuk belajar dan menelaah khazanah Islam khususnya sejarah peradaban Islam dimasa-masa yang akan datang.

\section{DAFTAR PUSTAKA}

A A’la Al-Maududi, 1985. Prinsip-prinsip Islam, Terj. Muslim A Kadir, Jakarta: Bulan Bintang.

Abd. A’la, 2003. Dari Neomodernisme ke Islam Liberal 2 Jakarta: Paramadina.

Ahmad Najib Berhan, 1962. Islam Dinamis, Kairo: Darul Fikri.

Ali Syanasi, 1982. Sosiologi Islam, Terj. Muslim A. Kadir, Jakarta: Bulan Bintang.

Fazlur Rahman Al Ansari, 1985. The Qur'anic Fondations and Structures of Muslim Society, Lahore: Islamic Publication Ltd.

Komarudin Hidayat, 1998. Tragedi Raja Midas, Jakarta: Paramadina.

Muhammad Abdul, 1962. Risalah of Tauhid, Kairo: Darul Fikri. 


\title{
CAGAR BUDAYA RELIGIUS SOMALANGU SEBAGAI DAERAH TUJUAN PARIWISATA DAN PUSAT STUDI ISLAM DI KABUPATEN KEBUMEN
}

\author{
Siti Habibah Aminah \\ Politeknik Dharma Patria Kebumen \\ e-mail: habibahsiti@gmail.com
}

\begin{abstract}
Abstrak
Pusat Studi Islam Kabupaten Kebumen dipresentasikan di Kawasan Komplek Somalangu dimana terdapat pondok pesantren, sekolah-sekolah, perpustakaan yang tersedia banyak sekali kitab-kitab kuno dan kitab-kitab yang lain. Dengan demikian keberadaan Cagar Budaya Religius Somalangu dan Pusat Studi Islam Kabupaten Kebumen tidak dapat dipisahkan dari keberadaan Cagar Budaya Religius Somalangu Sebagai Pariwisata Religi Dan Pusat Studi Islam Kabupaten Kebumen. Paket Wisata Religi yang dapat dijual di Kabupaten kebumen yang paling potensial yaitu Paket Wisata Cagar Budaya Religius Somalangu karena mempunyai daya tarik yang spektakuler tentang peninggalan budaya Islam yang paling dominan yaitu Masjid Kuno Al Kahfi Somalangu dan kegiatan Pondok Pesantren Somalangu yang merupakan laboratorium pendidikan Islam.
\end{abstract}

Kata Kunci: Cagar Budaya, Daerah Tujuan Pariwisata, Pusat Studi Islam.

\section{A. Pendahuluan}

Pembangunan nasional bertujuan untuk meningkatkan kesejahteraan masyarakat. Tujuan tersebut sesuai dengan Pembukaan Undang - Undang Dasar 1945 alinea keempat yaitu melindungi segenap bangsa Indonesia dan seluruh tumpah darah Indonesia, memajukan kesejahteraan umum, mencerdaskan kehidupan bangsa serta untuk melaksanakan ketertiban dunia 
yang berdasarkan kemerdekaan, perdamaian abadi, dan keadilan sosial. Pembangunan nasional merupakan rangkaian upaya pembangunan yang berkesinambungan di berbagai macam sektor antara lain sektor pariwisata. Lebih lanjut pengembangan pariwisata mencakup 2 dimensi yaitu ekonomi dan sosial budaya. Dilihat dari dimensi ekonomi, pengembangan pariwisata merupakan bagian dari upaya peningkatan daya saing produk wisata dan sekaligus menaikkan devisa. Dilihat dari dimensi sosial budaya , pengembangan pariwisata berupa meningkatkan peran serta pemerintah, dunia usaha dan masyarakat serta organisasi - organisasi pariwisata dalam koordinasi antar sektor dan antar lembaga.

Arah Tahapan Dan Prioritas Pembangunan Jangka Panjang Tahun 2005-2025 dengan mewujudkan bangsa yang berdaya saing serta membangun Sumber Daya Manusia yang berkualitas berupa kepariwisataan dikembangkan agar mampu mendorong kegiatan ekonomi dan meningkatkan citra Indonesia, meningkatkan kesejahteraan masyarakat lokal, serta memberikan perluasan kesempatan kerja.Pengembangan kepariwisataan memanfaatkan keragaman pesona keindahan alam dan potensi nasional sebagai wilayah wisata bahari terluas di dunia secara arif dan berkelanjutan, serta mendorong kegiatan ekonomi yang terkait dengan pengembangan budaya bangsa. ${ }^{1}$

\section{B. Pengembangan Cagar Budaya Religius Somalangu}

Pariwisata merupakan suatu aktivitas perjalanan yang dilakukan dari suatu tempat ke tempat lain. Ditinjau dari segi etimologis, kata "pariwisata" berasal dari bahasa sanskerta "pari" berarti banyak, berkali-kali, berputarputar, lengkap. Sedang "wisata" berarti perjalanan, bepergian. Pariwisata sebagai perjalanan yang dilakukan berkali-kali atau berputar-putar, dari suatu tempat ke tempat yang lain. ${ }^{2}$ Kata pariwisata dalam Bahasa Inggris disebut dengan kata tourist, sedang kata wisata disebut tour serta kepariwisataan digunakan kata tourism. ${ }^{33}$ Konsep pariwisata di Indonesia diketengahkan

\footnotetext{
Undang - Undang Republik Indonesia Nomor 17 Tahun 2007 tentang Rencana Pembangunan Jangka Panjang Nasional Tahun 2005-2025

2 Yoeti. 1977. Tour And Travel Management. Bandung

3 Priyo Darmanto\&Pujo Wiyoto. Kamus Inggris-Indonesia, Indonesia-Inggris, Arloka, Surabaya
} 
pada tanggal 12-14 Juni 1958 di Tretes Jawa Timur, kata tourisme diganti dengan kata "pariwisata". Kata pariwisata baru populer di Indonesia setelah Musyawarah Nasional Tourisme Ke II di Tretes Jawa Timur tersebut. Sehingga sampai sekarang istilah pariwisata sudah tidak asing lagi. Lebihlebih setelah terbentuknya Kabinet Pembangunan IV,V,VI, Bidang Pariwisata memperoleh departemen baru dengan nama : Departemen Pariwisata, Pos Dan Telekomunikasi, selanjutnya pada susunan Kabinet Pembangunan VII dan Kabinet Reformasi Pembangunan, Departemen Pariwisata, Pos Dan Terlekomunikasi menjadi Departemen Pariwisata seni Dan Budaya. Pada Kabinet Indonesia Bersatu II Periode 2009-2014 Kementerian Kebudayaan Dan Pariwisata diresufle menjadi Kementerian Pariwisata Dan Ekonomi Kreatif.

Cagar Budaya Relegius Somalangu merupakan aset budaya Islam yang besar yang didalamnya terdapat banyak potensi yang perlu dikembangkan sehingga tercipta Kawasan Cagar budaya Relegius Somalangu yang multiguna bagi kesejahteraan umat manusia di dunia. Sebagai salah satu aset Kawasan Somalangu adalah Pondok Pesantren Al Kahfi Somalangu telah memberi makna perjuangan yang panjang dan memberi peninggalan historis berupa terdapatnya berbagai situs, prasasti dan kepustakaan. Kajian sejarah berupa terdapatnya beberapa situs peninggalan sejarah dan beberapa prasasti menjadi alat ukur bagi kalangan intelektual dari berbagai disiplin ilmu untuk memberikan rekomendasi tentang pengembangan Cagar Budaya Religius Somalangu menjadi rujukan kajian kebudayaan Islam Somalangu dalam mengungkap sejarah peradapan Islam di kabupaten Kebumen. ${ }^{44}$

Pondok Pesantren Al Kahfi Somalangu berdiri seiring dengan tanda didirikannya sebuah Masjid yang kemudian dikenal sebagai Masjid Al Kahfi Somalangu. Masjid Al Kahfi Somalangu berdiri pada tahun 879 H (1.475 M). Ini sesuai dengan sebuah batu prasasti yang diketyemukan didalamnya yang kini disimpan oleh pimpinan pondok. Masjid didirikan pada hari Rabu tanggal 25 Sya'ban $879 \mathrm{H}$ atau 1.475 M. Pendirinya adalah seorang ulama dari Waliyulallah yang berasal dari Desa Jamhar, Hadaramaut, Yaman. Beliau bernama Syekh As Sayid Muhammad Ishom Al Hasani atau yang mashur

4 Poerna Sri Oetari, Master Plan Kawasan Cagar Budaya Religius Somalangu, Kebumen 2007 
belakangan dengan nama julukannya saja yaitu Syeh Abdul Kahfi. Beliau ini mendapat julukan orang sebagai Syekh Abdul Kahfi yang berarti Hamba Goa karena pernah hidup selama bertahun-tahun dari suatu goa ke goa lainnya dalam pengembaraan untuk menuntut ilmu di Negara Yaman. Masjid Pondok Al Kahfi Somalangu saat pertama kali dibangun dindingnya hanyalah berupa papan kayu dan bambu-bambu yang ditata rapi. Selain mustaka, atapnya terdiri dari daun ilalang, kayu sirap dan genteng kuno. Masjid Pondok Pesantren Al Kahfi Somalangu mulai ditembok dengan batu bata semenjak Pondok Pesantren ini diasuh oleh Syekh As Sayid Ibrahim Mahmud Al Hasani atau yang masyur dengan julukannya Syekh Abdul Kahfi mulai tahun 18651915. Semenjak saat itu sampai sekarang bangunan fisik masjid belum pernah mengalami pemugaran lama sekali. Beberapa kayu jendelanya memang telah mengalami tambal sulam akan tetapi tetap masih ada yang utuh dan asli semenjak saat didirikannya. Sekalipun demikian bangunan induk yang berupa saka guru dan mustaka masih tetap asli sebagaimana ketika awal didirikannya yaitu pada tahun $879 \mathrm{H}$ atau $1.475 \mathrm{M}$.

\section{Kebijakan Pengembangan Pariwisata}

Kepariwisataan merupakan bagian integral dari pembangunan nasional yang dilakukan secara sistematis, terencana, terpadu, berkelanjutan, dan bertanggung jawab dengan tetap memberikan perlindungan terhadap nilai-nilai agama, budaya yang hidup dalam masyarakat, kelestarian dan mtu lingkungan hidup, serta kepentingan nasional. Pembangunan kepariwisataan dilakukan berdasarkan asas manfaat, kekeluargaan, adil dan merata, keseimbangan, kemandirian, kelestarian, partisipatif, berkelanjutan, demokratis, kesetaraan dan kesatuan. ${ }^{5}$ Tujuan pembangunan kepariwisataan adalah: 1). Meningkatkan pertumbuhan ekonomi. 2). Meningkatkan kesejahteraan rakyat. 3). Menghapus kemiskinan. 4). Mengatasi pengangguran. 5). Melestarikan alam, lingkungan dan sumber daya. 6). Memajukan kebudayaan. 7). Mengangkat citra bangsa. 8). Memupuk rasa cinta yanah air. 9). Memperkukuh jati diri dan kesatuan bangsa. 10). Mempererat persahabatan antar bangsa.

Undang Undang Republik Indonesia Nomor 10 Tahun 2009 Tentang Kepariwisataan. 
Adapun tujuan operasional pembangunan pariwisata adalah mendatangkan wisatawan sebanyak mungkin dan menahan wisatawan selama mungkin serta membelanjakan uang wisatawan sebanyak mungkin. ${ }^{6}$ Kewenangan Pemerintah Pusat Di Bidang Kepariwisataan sebagai berikut :1). Menyusun dan menetapkan rencana induk pembangunan kepariwisataan nasional. 2) Mengkonsolidasikan pembangunan kepariwisataan lintas sektor dan lintas provinsi. 3) Menyelenggarakan kerja sama internasional di bidang kepariwisataan sesuai dengan peraturan perundang-undangan. 4) Menetapkan daya tarik wisata nasional. 5) Menetapkan destinasi pariwisata nasional. 6) Menetapkan norma, standar, pedoman, prosedur, kreteria, dan sistem pengawasan dalam penyelenggaraan kepariwisataan. 7) Memelihara, mengembangkan dan melestarikan aset nasional yang menjadi daya tarik wisata dan aset potensial yang belum tergali. 8) Melakukan dan memfasilitasi promosi pariwisata nasional. 9) Memberikan kemudahan yang mendukung kunjungan wisatawan. 10) Memberikan informasi dan atau peringatan dini yang berhubungan dengan keamanan dan keselamatan wisatawan. 11) Meningkatkan pemberdayaan masyarakat dan potensi wisata yang dimiliki masyarakat. 12) Mengawasi, memantau dan mengevaluasi penyelenggaraan kepariwisataan. 13) Mengalokasikan anggaran kepariwisataan.

Kewenangan Pemerintah Provinsi Jawa Tengah Di Bidang Kepariwisataan sebagai berikut: 1) Menyusun dan menetapkan rencana induk pembangunan kepariwisataan provinsi. 2) Mengkoordinasikan penyelenggaraan kepariwisataan di wilayah. 3) Melaksanakan pendaftaran, pencatatan dan pendataan pendaftaran usaha pariwisata. 4) Menetapkan destinasi pariwisata provinsi. 6) Menetapkan daya tarik wisata provinsi. 7) Memfasilitasi promosi destinasi pariwisata dan produk pariwisata yang berada di wilayahnya. 8) Memelihara aset pariwisata yang menjadi daya tarik wisata provinsi. 9) Mengalokasikan anggaran kepariwisataan.

Kewenangan Pemerintah Kabupaten/Kota Di Bidang kepariwisataan sebagai berikut: 1) Menyususun dan menetapkan rencana induk pembangunan kepariwisataan Kabupaten/Kota. 2) Menetapkan destionasi

${ }^{6}$ Abdullah. 2010. Kebijakan Dan Kode Etik Pariwisata. Fakultas Ilmu Budaya Universitas Gadjah Mada Yogyakarta. 
pariwisata Kabupaten/Kota. 3) Menetapkan daya tarik wisata Kabupaten/ Kota. 4) Melaksanakan pendaftaran, pencatatan dan pendataan pendaftaran usaha pariwisata. 5) Mengatur penyelenggaraan pengelolaan kepariwisataan di wilayahnya. 6) Memfasilitasi dan melakukan promosi destinasi pariwisata dan produk pariwisata yang berada di wilayahnya. 7) Memfasilitasi pengembangan daya tarik wisata baru. 8) Menyelenggarakan pelatihan dan penelitian kepariwisataan dalam lingkup Kabupaten/Kota. 9) Memelihara dan melestarikan daya tarik wisata yang berada di wilayahnya. 10) Menyelenggarakan bimbingan masyarakat sadar wisata. 11) Mengalokasikan anggaran kepariwisataan.

\section{Pengembangan Pusat Studi Islam Di Kabupaten Kebumen}

Islam yang disebarkan di kawasan Asia Tenggara telah lengkap dengan berbagai aliran kalam, fiqh, tasawuf, dan tarekat yang dikembangkan oleh ulama sebelumnya. Terdapat 2 kecenderungan umat Islam saat itu yaitu golongan tradisional yang meningkatkan diri pada madzab atau aliran tertentu dan golongan modernis yang menganggap bahwa kemunduran Islam karena pelaksnaan ajaran yang sudah tidak murni lagi. Pembaharuan yang terjadi di dunia Islam dipelopori oleh ulama modernis di berbagai negara, yaitu Muhammad Ibnu Abdul Al Wahab di Saudi Arabia, Jamaludin Al Afgani, Muhammad Abduh, dan rosyid Ridho di Mesir berdampak ke Indonesia bersamaan dengan kembalinya Haji Miskin pada tahun 1802 setelah melakukan ibadah haji dari Mekah.

Pembaharuan pemahaman agama Islam ditujukan untuk: 1). Mensucikan Islam dari pengaruh bid'ah. 2). Pendidikan yang lebih tinggi bagi umat Islam. 3). Pembaharuan rumusan ajaran Islam menurut alam pikiran medern. 4). Pembelaan Islam terhadap pengaruh barat dan kristen. ${ }^{7}$ Pembaharuan di Indonesia ditandai dengan berdirinya berbagai organisasi Islam. Organisasi tersebut antara lain, Jamiyatul Khair didirikan di Jakarta pada tahun 1905. Perkumpulan ini lebih banyak bergerak di bidang pendidikan dan mendidik generasi muda untuk meneruskan perjuangan Islam. Mathla'ul Anwar merupakan organisasi sosial keagamaan yang lebih banyak bergerak di bidang

Dedi Supriyadi. 2008. Sejarah Peradapan Islam. Pustaka Setia. Bandung. 
pendidikan pada tahun 1905 di Menes Banten oleh KHM Yasin, politik mereka disalurkan melalui Syarikat Islam. Muhammadiyah didirikan pada tanggal 18 November 1912 di Yogyakarta, pendirinya adalah KH Ahmad Dahlan. Persatuan Indonesia (Persis) didirikan di Bandung pada tahun 1923 yang dipimpin oleh A.Hasan. Nahdlatul Ulama didirikan di Surabaya pada tanggal 31 Januari 1926 oleh KH Muhammad Hasyim Asy’ari dan berbagai organisasi keagamaan lainnya yang tumbuh pada masa reformasi.

Pondok Pesantren Al Kahfi Somalangu Kabupaten Kebumen sebagai pusat rujukan pembelajaran agama, sejarah dan kebudayaan Islam. Pondok pesantren tersebut merupakan salah satu pesantren tertua di Jawa yang masih memiliki eksistensi sampai saat ini. Warisan tertua yang ada dan dapat dirasakan oleh semua masyarakat salah satunya adalah bangunan masjid yang masih kokoh berdiri dengan ornamen dan struktur arsitektur yang asli. Didirikan 2 tahun sebelum Masjid Demak yaitu 1.475 M. masjid ini merupakan saksi sejarah bahwa peradapan Islam mulai dibangun di tempat tersebut beberapa abad silam. Sebagai pendiri dan pengasuh pondok pesantren pertama Sayid As Syekh Muhammad Ishom Al Hasani atau yang lebih dikenal dengan Syekh Abdul Kahfi adalah seorang intelektual yang produktif menerbitkan berbagai pemikirannya menjadi berbagai buku (manuskrip). Disamping itu beliau juga kaya akan koleksi kepustakaan yang dikumpulkan dari berbagai penulis waktu itu. Beliau juga merupakan salah satu ulama sepuh yang sangat berpengaruh di jaman kepemimpinan Raden Fatah sebagai raja waktu itu.

Sebagai ulama sekaligus menantu raja Syekh Abdul Kahfi merupakan tokoh yang sangat berpengaruh terhadap syiar Islam, pengambilan keputusan kerajaan dan kerjasama pengembangan kerajaan. Syekh Abdul Kahfi mewarisi pesantren yang terus menjadi salah satu Pusat Pendidikan Islam di Jawa, sehingga melahirkan berbagai tokoh ulama yang tersebar di kepulauan nusantara. Kharisma ketokohan maupun tradisi intelektualnya terus diwariskan sehingga mewariskan kekayaan kepustakaan atau manuskrip dan dokumen tua dan peninggalan lain berupa situs sejarah, benda-benda peninggalan atau prasasti, senjata-senjata peninggalan bersejarah yang sangat bernilai secara historis maupun bagi bagi pengembangan kebudayaan Islam. 


\section{E. Korelasi Pengembangan Pariwisata Religi Cagar Budaya Somalangu Dengan Pusat Studi Islam Di Kabupaten Kebumen}

Pengembangan dan pembangunan pariwisata di Indonesia dilandasi oleh Undang-undang Republik Indonesia Nomor 10 Tahun 2009 Tentang Kepariwisataan, dan Visi Pembangunan Nasional 2005-2025 yaitu Indonesia Yang Mandiri, Maju, Adil Dan Makmur, sedang Misi Pembangunan Nasional yaitu: 1). Mewujudkan masyarakat berahlak mulia, bermoral, berbudaya dan beradab berdasarkan falsafah Pancasila. 2). Mewujudkan bangsa yang berdaya saing. 3). Mewujudkan masyarakat demokratis berdasarkan hukum. 4). Mewujudkan Indonesia aman, damai dan bersatu. 5). Mewujudkan pemerataan pembangunan dan dan keadilan. 6). Mewujudkan Indonesia asri dan lestari. 7). Mewujudkan Indonesia menjadi negara kepulauan yang mandiri, maju, kuat dan berbasiskan kepentingan nasional. 8). Mewujudkan Indonesia berperan penting dalam pergaulan dunia internasional. Pembangunan kepariwisataan dikembangkan agar mampu mendorong kegiatan ekonomi dan meningkatkan citra Indonesia, meningkatkan kesejahteraan masyarakat lokal, serta memberikan perluasan kesempatan kerja. Pengembangan kepariwisataan memanfaatkan keanekaragaman pesona keindahan alam dan potensi nasional sebagai wilayah pariwisata bahari terluas di dunia secara arif dan berkelanjutan, serta mendorong kegiatan ekonomi yang terkait dengan pengembangan budaya bangsa. Pembangunan aparatur negara dilakukan melalui reformasi birokrasi untuk meningkatkan profesionalisme aparatur birokrasi dan untuk mewujudkan tata pemerintahan yang baik, di pusat maupun di daerah agar mampu mendukung keberhasilan pembangunan di bidang-bidang lainnya.

Sedangkan Visi Pembangunan Kementerian Pariwisata menggunakan pijakan visi Presiden Republik Indonesia pereode 2014-2019 yaitu Terwujudnya Indonesia Yang Berdaulat, Mandiri Dan Berkepribadian Berlandaslan Gotong Royong. Visi tersebut merupakan bagian dari 9 agenda prioritas Pemerintah yang disebut dengan Nawacita. Agenda pariwisata termasuk dalam agenda prioritas keenam yaitu Meningkatkan Produktivitas Rakyat Dan Daya Saing Di Pasar Internasional Sehingga Bangsa Indonesia Dapat Maju Dan Bangkit Bersama Bangsa-Bangsa Asia Lainnya. Dalam rangka meningkatkan daya saing dengan memanfaatkan potensi yang belum dikelola dengan baik serta 
pengembangan pariwisata yang berdaya saing di pasar internasional, sekaligus memberi peluang besar untuk meningkatkan akselerasi pertumbuhan ekonomi nasional. Sektor pariwisata akan meningkatkan daya saing Indonesia, dengan memanfaatkan potensi yang selama ini belum dikelola optimal, salah satunya adalah potensi maritim, semata-mata untuk meningkatkan akselerasi pertumbuhan ekonomi nasional.

Adapun misi Kementerian Pariwisata 2015-2019 memuat empat pilar pembangunan kepariwisataan sebagai berikut: 1) Mengembangkan destinasi pariwisata yang berdaya saing, berwawasan lingkungan dan budaya dalam meningkatkan pendapatan nasional, daerah dan mewujudkan masyarakat yang mandiri. 2) Mengembangkan produk dan layanan industri pariwisata yang berdaya saing internasional, meningkatkan kemitraan usaha, dan bertanggung jawab terhadap lingkungan alam dan sosial budaya. 3) Mengembangkan pemasaran pariwisata secara sinergis, unggul, dan bertanggung jawab untuk meningkatkan perjalanan wisatawan nusantara dan kunjungan wisatawan mancanegara sehingga berdaya saing di pasar internasional. 4) Mengembangkan organisasi Pemerintah, Pemerintah Daerah, swasta dan masyarakat, sumber daya manusia, dan mekanisme operasional yang efektif dan efisien serta peningkatan kerjasama internasional dalam rangka meningkatkan produktifitas pengembangan kepariwisataan dan mendorong terwujudnya pembangunan kepariwisataan yang berkelanjutan. ${ }^{8}$

Pengembangan Pariwisata Religi Cagar budaya Religius Somalangu merupakan aset besar pariwisata yang terkait dengan agama atau kepercayaan, spiritual. Pariwisata religi yaitu jenis wisata ini sedikit banyak dikaitkan dengan agama, sejarah, adat-istiadat dan kepercayaan umat atau kelompok dalam masyarakat. (Pendit, 2006:41). Cagar Budaya Religius Somalangu sebagai Pariwisata Religi dibuktikan dengan banyaknya peninggalan budaya Islam dan keterkaitannya, sebagai berikut: 1) Masjid Al Kahfi Somalangu 2) Pantai Syihr Hadramaut Yaman 3) Pantai Karangbolong 4) Sungai Puring 5) Bangunan Candi Somalangu 6) Peninggalan Candi di Candiwulan Candimulyo 7) Desa Candi Kecamatan Karanganyar 8) Pondok Pesantren Al Kahfi Somalangu 9)

8 Peraturan Menteri Pariwisata Nomor 29 Tahun 2015 Tentang Rencana Strategis Kementerian Pariwisata. 
Mimbar Masjid (mihrab) 10) Mustaka Masjid 11) Batu Prasasti 12) Ukiran Bulus Berkaki Tiga 13) Tiang Masjid 14) Manuskrip Tua 15) Yoni 16) Makam Kertayasa 17) Makam Lemah lanang 18) Kitab-kitab kuno dan kitab-kitab lainnya.

Beberapa Konsep Pengembangan Cagar Budaya Religius Somalangu yang perlu diperhatikan sebagai berikut: 1) Masjid Al Kahfi Somalangu 2) Bangunan Asrama Lama 3) Pengembangan Asrama Santri 4) Pembangunan Museum 5) Pembangunan Perpustakaan 6) Pembangunan Kawasan Lingga dan Yoni 7) Pengembangan Madrasah Ibtidaiyah 8) Pengembangan Madrasah Tsanawiyah 9) Pengembangan Madrasah Aliyah 10) Perencanaan Pengembangan Perguruan Tinggi Islam 11) Zona Aktivitas Out Door 12) Zona Parkir 13) Penataan makam Lemah Lanang 14) Zona Cafetaria dan Wisata Kuliner 15) Pembangunan Pusat Informasi.

Pusat Studi Islam Kabupaten Kebumen dipresentasikan di Kawasan Komplek Somalangu dimana terdapat pondok pesantren, sekolah-sekolah, perpustakaan yang tersedia banyak sekali kitab-kitab kuno dan kitab-kitab yang lain. Dengan demikian keberadaan Cagar Budaya Religius Somalangu dan Pusat Studi Islam Kabupaten Kebumen tidak dapat dipisahkan dari keberadaan Cagar Budaya Religius Somalangu Sebagai Pariwisata Religi Dan Pusat Studi Islam Kabupaten Kebumen. Paket Wisata Religi yang dapat dijual di Kabupaten kebumen yang paling potensial yaitu Paket Wisata Cagar Budaya Religius Somalangu karena mempunyai daya tarik yang spektakuler tentang peninggalan budaya Islam yang paling dominan yaitu Masjid Kuno Al Kahfi Somalangu dan kegiatan Pondok Pesantren Somalangu.

Paket Wisata atau package tour adalah suatu tour yang direncanakan dan diselenggarakan oleh suatu Travel Agent atau Tour Operator atas resiko dan tanggung jawab sendiri, dimana acara, lama waktu tour, obyek-obyek yang akan dikunjungi, akomodasi, transportasi serta makanan dan minuman telah ditentukan dalam suatu harga yang sudah ditentukan pula jumlahnya. ${ }^{99}$ Selain Pariwisata Religi Somalangu terdapat kunjungan paket wisata terkenal lainnya di Kabupaten Kebumen yaitu Geowisata Karangsambung berupa Kawasan Cagar Alam Geologi Karangsambung yang terdapat laboratorium alam batu-

$9 \quad$ Yoeti. 1977. Tour And Travel Management. Bandung. 
batuan kuno yang spektakuler bertingkat internasional. Kabupaten Kebumen juga mempunyai Kawasan Ecocartedutourism Gombong Selatan yaitu Kawasan Pegunungan Seribu yang merupakan Kawasan Ecocart Gombong Selatan untuk pendidikan dan pariwisata minat khusus kegoaan (speologi) seperti Goa Jatijajar, Goa Petruk dan ratusan goa-goa yang ada di Pegunungan Seribu Gombong Selatan. Kabupaten Kebumen juga mempunyai potensi Kawasan Strategis Pariwisata Karangduwur berupa kawasan pariwisata darat, kawasan pariwisata laut, kawasan pariwisata dirgantara. Kawasan-kawasan tersebut merupakan resort atau tempat peristirahatan yang spektakuler karena sangat lengkapnya kegiatan pariwisata.

\section{F. Kesimpulan}

Ada korelasi yang signifikan antara Pariwisata Religi Cagar Budaya Religius Somalangu dengan Pusat Studi Islam Kabupaten Kebumen. Korelasi Pariwisata Religi dengan Pusat Studi Islam Kabupaten Kebumen mengarah pada hubungan sinergi dan integrasi antara kedua fariabel tersebut sebagai berikut: Pertama, Pertumbuhan ekonomi pada Kawasan Pariwisata Religi Cagar Budaya Religius Somalangu merupakan leading sector ke lagging sector artinya bahwa pengembangan suatu kawasan pariwisata maupun kawasan ekonomi pada daerah tertentu merupakan sektor andalan sehingga dapat memimpin atau mempengaruhi sektor-sektor lain. Tumbuhnya sektor informal seperti home industri dapat tumbuh dengan dikembangkannya kawasan pariwisata. Pengembangan suatu daerah menjadi kawasan pariwisata akan terjadi trickle down effect artinya pusat daerah pariwisata yang dikembangkan akan menumbuhkan berbagai jenis pariwisata di sekitar lokasi pariwisata tersebut. Kedua, Pengembangan Daerah Tujuan Pariwisata juga dapat menimbulkan multiflier effect sehingga masyarakat sekitar lokasi pariwisata tersebut akan terkena dampak pengembangan kawasan pariwisata. Dampak pengembangan tersebut akan dirasakan langsung oleh pelaku pariwisata di daerah setempat. Daerah Tujuan Pariwisata tetap memperhatikan Sapta Pesona akan dapat menciptakan kepuasan wisatawan sehingga mereka akan mengulang perjalanannya (repeat bussines). Ketiga, Cagar Budaya Religius Somalangu merupakan Pariwisata Religi dengan daya tarik pariwisata utama Cagar Budaya 
berupa Masjid Al Kahfi Somalangu. Pusat Studi Islam Kabupaten Kebumen tidak dapat terpisahkan dengan Cagar Budaya Religius Somalangu sehingga korelasi yang terjadi adalah sinergi dan integrasi.

\section{DAFTAR PUSTAKA}

Abdullah. 2010. Kebijakan Dan Kode Etik Pariwisata. Fakultas Ilmu Budaya Universitas Gadjah Mada Yogyakarta.

Dedi Supriyadi. 2008. Sejarah Peradapan Islam. Pustaka Setia. Bandung.

Pendit Nyoman S. 2006. Ilmu Pariwisata Sebuah Pengantar Perdana. Pradnya Paramita. Jakarta.

Poerna Sri Oetari, Master Plan Kawasan Cagar Budaya Religius Somalangu, Kebumen 2007

Peraturan Menteri Pariwisata Nomor 29 Tahun 2015 Tentang Rencana Strategis Kementerian Pariwisata.

Priyo Darmanto\&Pujo Wiyoto. Kamus Inggris-Indonesia, Indonesia-Inggris, Arloka, Surabaya

Undang Undang Republik Indonesia Nomor 10 Tahun 2009 Tentang Kepariwisataan.

Undang-Undang Republik Indonesia Nomor 17 Tahun 2007 tentang Rencana Pembangunan Jangka Panjang Nasional Tahun 2005-2025

Yoeti. 1977. Tour And Travel Management. Bandung. 